HAKAN SARI

Necmettin Erbakan University, Turkey

hakansari@gmail.com

DOI: 10.13166/JMS/95049

JOURNAL OF MODERN

HATICE GÖKDAĞ

Necmettin Erbakan University, Turkey

gokdaghatice@hotmail.com

AHSEn Ela KIZILKAYA

Karamanoğlu Mehmetbey University, Turkey

ahsenkizilkaya@gmail.com

\title{
Evaluation of Special Education Teachers' OPINIONS ABOUT LITERACY TEXTBOOKS, TEACHING INDIVIDUALS WITH INTELLECTUAL DisABILITIES
}

\begin{abstract}
Objectives: The overall aim of the study is to evaluate the textbooks used in teaching literacy for students with intellectual disabilities in terms of teacher opinions.

Material and methods: It is a qualitative research. Semi-structured interview method was chosen in the research among interview types included in qualitative research methods. The research was carried out with the participation of teachers in the sub-special classes within the primary schools and Vocational Training Centres affiliated to the Directorate of National Education in Konya. Sixteen teachers, eight male, and six female participated in the survey voluntarily. Five of the teachers are from the Special Education Department, five are from the Class Teacher, and six are graduated from different departments and have an average of twelve years of professional experience. Teachers have experience in teaching literacy skills to students with intellectual disabilities for at least six years of their professional lives.

Results: As regarding the textbook used in the literacy teaching, the teachers stated that the books used in literacy teaching are written in plain text and that the plain writing is appropriate. They pointed out the importance of its being suitable for daily life, the ability of children with intellectual disabilities to grasp the straight line more easily, and it is also easy writing in terms of motor development.
\end{abstract}


Conclusions: Children with intellectual disabilities learn to read and write at the same stages as normal children. However, this process is long-lasting. In the reading and writing process, the curriculum should be determined according to the needs of the learners and the activities should be increased, designed to appeal to the greatest possible senses, the motivation of the students should be kept at the highest level.

KEYWORDS: special education, Individuals with special education needs, literacy, textbook, intellectual disabilities.

\section{INTRODUCTION}

The acquisition of reading and writing skills forms the basis for learning and at the same time has an important place in school life for students. Teaching life that starts with primary school literacy education continues throughout education life of the student.

Literacy is the backbone of school programs and has a very important place almost in every school subject (Özdemir, 1987). The success that a student will show in his or her classroom is proportional to the degree to which he has gained his reading ability. While a literate student is likely to be successful in school life, it is very difficult to succeed in his class for a student who cannot read well or cannot fully understand what he is reading (Çelenk, 2003).

Literacy teaching should not be considered as a study that fits into several months in primary classes of primary schools. The development of literacy skills continues even after the first literacy skills have been gained, improving the correct and proper use of the mother tongue. The aim of literacy teaching is; to gain the basic skills of reading and writing that will be used during the life by way of basic skills such as speaking, listening, visual reading and presentation, and to bring the students to a functional reading and writing level. Functional literacy is to develop these acquired skills to a level that can be used in everyday situations where it is needed. In line with this goal, basic habits that will give functional literacy ability to the students should be given from the beginning of primary school (Kavcar, Oğuzkan, Sever, 1998, Öz, 2005).

In order to enable individuals to live independently in the society, various knowledge and skills requirements are met with educational activities carried 
out in schools and school life is to prepare the students for the society life. For this, functional knowledge and skills are taught that will enable individuals to use in their daily lives and make their lives easier. The same is true for students with intellectual disabilities. The main purpose of these students' education is to provide them with functional skills and to develop their independent living skills so that they can become independent within the society. To achieve this, students with intellectual disabilities need to be acquired: basic development skills, necessary numerical information in daily life, necessary skills in daily life (appropriate level) such as reading and communication (Cavkaytar, 2001). Acquiring academic skills for students with intellectual disabilities are as important as communication skills, business skills and social skills in maintaining their lives in the school period and after school (Yıkmış, 1999). It is therefore important for students with intellectual disabilities to have a functional skill that will enable them to manage themselves at all times in their lives.

To enable individuals with intellectual disabilities to sustain in their daily lives and participate in social life such as regularly developing individuals can also be provided with the education. Through education, individuals can meet their needs, communicate with people around them and eventually become a producer and independent person in society. Many of the educational activities are based on reading and writing, understanding, speaking and communicating (Çolak, 2001). Teaching reading to students with intellectual disabilities provides a basis for teaching functional academic skills, as well as helping them to improve their self-confidence, socialize, and support their mental and motor development. For this reason, reading skills should be taught depending on the performance and needs of students with intellectual disabilities (Başal and Batu, 2002).

The need for teaching literacy skills to children with intellectual disabilities has emerged after the 60 s of the $20^{\text {th }}$ century, with the establishment of primary schools for children with mental disabilities. The opinions and attitudes of the experts in this regard are initially quite negative. Koller (1969) interpreted this as a celebration of a skill that continues to be 'useless ballast' for individuals with intellectual disabilities. Bach (1977) considered that teaching reading to individuals 
with intellectual disabilities is a little dubious and a waste of time, as reading is a rather complex code-analysis.

Speck (1975), on literacy competence, points out that literacy teaching cannot be the primary goal of learning in school for mentally retarded people. The fact that the literacy skills of these children play a minor role in their post-school life indicates that the teaching of other skills for later life management is more important for individuals with intellectual disabilities.

Significant changes have been recorded in the attitudes towards literacy teaching to individuals with intellectual disabilities since the 1980s, and reading and writing instruction for mentally retarded students have included in the school curriculum (Anstötz, 1987). Practice of reading and writing in the school curriculum for the individuals with intellectual disabilities is an important element in terms of social and cultural participation in a democratic, equal society (Koch, 2008). It is imperative to read and write in terms of cultural heritage access. It is quite difficult for individuals who do not have this achievement to participate in social life. In UNESCO (1978), there is a statement that literacy is a fundamental right, including individuals with intellectual disabilities (Koch, 2008).

When the sources of literacy teaching published in western countries are examined, it is seen that the teaching is based on the word and letter method. The methods used in teaching literacy in Turkey shows that differentiation by Western countries, as Turkish literacy system is different from many other languages. Different methods have been used in the first literacy teaching since the Republic. In the historical process; the method of voice and word, the mixed method with the word method in the 1926 Primary Curriculum, the sentence method in the 1936 Primary Curriculum and after the year 2005 in the Primary Turkish Course the Sound Based Sentence Method were adopted as in the first literacy program (Bay, 2006). However, there is no specific literacy teaching method specific to children with intellectual disabilities. It is not possible to mention one method of teaching reading and writing to students with intellectual disabilities. Considering individual differences, studies are being conducted with any literacy teaching method (letter, syllable, word, mixture, analysis, etc.) that the student may be successful in (M.E.B., 
2001). The mental level of the child requires the choice of either functional reading instruction or one of the literacy teaching methods (Browder and Snell, 2000). Method diversity should include applications that address primarily the learning styles and needs of students (Baş, 2006). To decide which method will be adopted; the learning characteristics of the student, learning preferences, and other teaching programs should be considered (Love and Litton, 1994).

Children with intellectual disabilities, as well as students with normal development, also have problems in the process of gaining literacy skills. It is stated that these children particularly have difficulty in distinguishing letters, letter-voice mapping, reading a new word, recognizing words, analyzing and understanding what they read (Gunning, 1996). These difficulties are usually due to the teaching method used. It is suggested that with instructional programs provided by the appropriate instructional strategy, and adequate instructional materials, students with intellectual disabilities can develop their literacy skills (Hoogeveen et al., 1989). In addition, activities in literacy teaching for students with intellectual disabilities should be able to appeal to as many sensory organs as possible (Çelenk, 1999, Güleryüz, 2000, Koksal, 2000, Nas, 1999).

In the literature, it is noteworthy that the researches on teaching reading and writing to students with intellectual disabilities are very limited. Çolak in Turkey (2001) made the study 'Special Education Teachers' Opinions and Suggestions, Working at Mental Retardation Elementary School and Vocational Training Centers, on Literacy Learning of Children with Intellectual Disabilities". Çolak (2001) has taken the views of seven special education teachers working in elementary school or vocational training center for individuals with intellectual disabilities. In this qualitative study, it was concluded that children with mental retardation gain reading and writing through normal stages of development, but that they can learn to read and complete these stages for a longer time than children with normal development. In addition, it was determined that the inadequate equipment and the level differences among the students, the families not adequately supporting the children at home were the main problems. Başal and Batu (2002) evaluated the opinions and suggestions of the sub- 
special class teachers about teaching reading and writing to children with intellectual disabilities. In this research, semi-structured interviews were conducted with seven sub-special class teachers in Eskişehir. According to the findings obtained from the research, it was determined that the teachers used different methods in reading and writing teaching, they used sentence method more frequently in literacy teaching, but also used different methods in necessary situations. In addition, teachers stated that family support is essential for effective teaching, and problems such as lack of equipment and resources should be addressed.

Research done abroad on reading and writing teaching to individuals with intellectual disabilities seems to be limited. Katims (2001-2002) studied the literacy skills of students with 132 mild and moderate mental retardation disorders who were educated in schools in San Antonio, Texas, using adult treading inventory (ARI) and found that 44 (33\%;) can read short texts. Some students have had a good reading ability despite having a lower IQ level compared to other students and this result lead Katims to early and intensive support (Katims, 2002).

In a project conducted by the Southern Methodist University in the Fort Worth School District in Texas, the learning status of mild and intermediate students to read and write was analyzed and the question of how well mentally retarded students are able to gain literacy skills were tried to be answered. During the study, a total of 150 students were studied in ten different schools. Half of the pupils continued intensive reading lessons for about an hour a day while the other half continued to be trained according to the normal program of mental retardation school. The results showed that the students taking intensive course achieved significantly better results than the students according to the usual methods (SMU, 2005).

Oberacker (1980) found that 30 students (33\%) of 91 students attained literacy skills in a study of literacy learning with mentally retarded students in Stuttgart, he determined that $25 \%$ of students aged between 16 and 18 can read unknown texts.

Çolak (2001), Basal and Batu (2002) stated that teachers emphasized the importance of materials and resources used in teaching reading and writing to students with intellectual disabilities. 
In this study, the opinions of teachers, who are special education graduates and are not special education graduates working in the special education school, on the textbooks used in teaching literacy to students with mild intellectual disabilities, are evaluated. It is hoped that the findings obtained from the study will guide educators working with children with intellectual disabilities on the tools and resources they will use in teaching literacy. The overall aim of the study is to evaluate the textbooks used in teaching literacy for students with intellectual disabilities in terms of teacher opinions. In response to this general objective, the following questions were sought:

1. What type of writing is used in books you use in literacy? What is your opinion about the type of writing used?

2. What is your opinion about the type of activity (read, write, scan and write, etc.) and number of activities given in the books you use about literacy?

3. What do you think about the appropriateness of letter-combining activities in the books you use in literacy?

4. What do you think about the appropriateness of syllabus-related activities in books you use in literacy?

5. What do you think about the readings in books you use in literacy?

6. Is it concerned with reading or writing more in books you use in literacy? What is your opinion on this?

7. Have tips on reading vocabulary used (pictures, etc.)? What is your opinion?

8. What do you think about the suitability of the books you use in literacy to IEP goals?

9. Do you need additional reading and writing material? How do you supply it?

10. What do you think about efficiency for homework of the literacy books you use?

\section{Method}

In this chapter; the design of the study, the study group, the data collection process and the analysis of the data are placed. 


\section{Study Design}

Semi-structured interview method was chosen in the research among interview types included in qualitative research methods. According to Karasar (2010), interview (interview) is a technique of data collection (investigation) by verbal communication. In a semi-structured interview technique, the researcher prepares a protocol for interviews, including questions that he I she wants to ask in advance. However, depending on the progress of the interviewer, the investigator may influence the flow of the interview with different side or sub questions, leading the person to open the answers and explain in more detail (Türnüklü, 2000). The semi-structured interview technique provides great convenience to the researcher because it provides more systematic and comparable information because the interviewer is based on the pre-prepared interview protocol (Yildırım and Şimşek, 2004). The main aim of the qualitative research is to investigate the emotions and thoughts of the research problem in depth. The purpose of using the qualitative research method in the research is to get deeper and more detailed information from the selected study group (Ylldırım and Simsek, 2006).

\section{Study Group}

The research was carried out with the participation of teachers in the subspecial classes within the primary schools and Vocational Training Centres affiliated to the Directorate of National Education in Konya. Sixteen teachers, eight male and six female, participated in the survey voluntarily. Five of the teachers are from the Special Education Department, five are from the Class Teacher, and six are graduated from different departments and have an average of twelve years of professional experience. Teachers have experience on teaching literacy skills to students with intellectual disabilities for at least six years of their professional lives. The names of the teachers who participated in the interview were not used and the interview forms were numbered.

\section{Data Collection}

For the purpose of research, a question pool was formed by literature review in the process of preparation of the interview questions as it should be in the semi-structured interview technique. Semi-structured interview form 
was prepared by selecting the most appropriate questions from the question pool created in line with the opinions of the experts working in the field of special education. Material expressions were rearranged in line with opinions and feedback from experts. The forms which edited and amended statements take place were sent back to the experts for review. The items shaped in the light of the arrangements made are formulated as follows:

1) In the pilot study, the questions in the Interview Forms were asked to three teachers, and the unexplained expressions were asked again and corrected.

2) The interview questions were reviewed by three experienced specialists in qualitative research in order to bring the unrecognized items into a more understandable form after the pilot work.

3) Semi-structured Interview Forms given in the final form for the application.

\section{Data Analysis}

Following the completion of the interviews, the voice recordings of the interviews made with the participants were analyzed, the data in the interview form was scripted into texts, and the interview coding key was created by evaluating the records one by one. One of the interviews was selected and evaluated by one of the researchers and one of the experts independently from each other according to the interview coding key. In order to determine its consistency, the coding key was given the final shape by comparing the markings made by the researcher and the expert in the coding key and making the necessary changes. For each teacher participating in the interview, the coding keys filled by the researcher and the expert were compared for consistency. In the calculation of the reliability of the studies, the 'Consensus/ Consensus + Dissensus' formula was used. All of the questions in the semistructured interview form formed a consensus / consensus.

\section{Findings}

In this section, the opinions and evaluations of the teachers who participated in the interviews about the textbooks used for teaching literacy to students with intellectual disabilities are presented. 


\section{Comments on the Writing Type in Books Used in Literacy}

All of the teachers who participated in the interviews stated that the books used in the literacy teaching were written in plain text and that the plain writing was appropriate. They pointed out the importance of its being suitable for daily life, the ability of children with intellectual disabilities to grasp the straight line more easily, and it is also easy writing in terms of motor development. A participant in the interview said: "I think that plain writing is more effective and easier for students with mild mental intellectual disabilities. I spend my handwriting sources writing in their books in plain text and use them like that. I affix their images to their books' (Teacher, 8). Another teacher said 'Books usually use plain text. These children are easier to learn and write straight. He does not use handwriting anymore in upper grades' (Teacher: 11).

\section{Opinions Regarding the Types and Number of Activities in Books Used Literacy Teaching}

$68.7 \%$ (11) of the interviewed teachers stated that the activities in the textbooks used for teaching literacy to students with intellectual disabilities did not fit the level of these children and that the number of activities was also insufficient. Teachers stated that the activities in the books are mostly visual and auditory, and that these students should be given activities and games that appeal to different senses while teaching reading and writing. As an example to this view, one participant states: 'I think that the type and number of activities are not sufficient. There should be more examples of activities that are not limited only visually and audibly. The number of pages should be sufficient for plenty of repetition. These students need more retrospect. Especially for our students it is very inadequate and superficially prepared. The order of teaching is not changed in these children but it is very inadequate in number "(Teacher, 7). In another example, there are the following views; 'The books and the activities are not enough. I think that the existing activities do not appeal to children in general. I am using materials that I have provided for myself "(Teacher, 2). Another teacher participating in the interview states: 'The books given in the literacy teaching by National Education are the same as those used in the literacy teaching for normal 
children. These children are special and their books should be different from the other children; more interesting, motivating activities and the writing should be a little bigger "(Teacher, 15).

$31 \%$ (5) of the teachers who participated in the study stated that the activities included in the books used in the literacy teaching were adequate in terms of type and number. Teachers who give opinion that it is enough are teachers who graduated from different departments.

\section{Opinions Regarding the Appropriateness of Activities Related to Letter-Combining in Books Used in Literacy Teaching}

All of the interviewed teachers stated that letter combination was a convenient method for students with intellectual disabilities, but $87.5 \%$ of the participants (14 teachers) indicated that the activities used in the books were inadequate for these children. A teacher's view of the issue is an example of the teacher's views that support this end result: 'There is no special book distribution for these students in literacy teaching. We use textbooks prepared for normal students. However, these books are not suitable for children with mental retardation. As a visual material, both repetition and writing are inadequate. There should be more activities appropriate to the level of the child '(teacher, 16).

Two of the interviewed teachers (12.5\%) expressed their opinion that the activities related to letters combining in books used in teaching literacy for intellectually disabled students were appropriate and sufficient.

\section{Opinions Regarding the Appropriateness of Activities Related to Syllabification in Books Used in Literacy Teaching}

All of the interviewed teachers stated that the activities given as an example of syllabification are appropriate, but they are very inadequate in terms of the number of activities. They are united about increasing the number of vocabulary for better understanding of learners, as well as different activities such as play, drama, etc., so that the activities should be enhanced to appeal to as many audios as possible. The following example supports the idea: After the syllable has been combined, the work is finished in one or two lines and the student ends before he / she understands. Activity 
examples are very inadequate. There should be different activities besides reading and writing activities' (Teacher, 5).

\section{Opinions Concerning the Sentences on Reading in Books Used in Teaching literacy}

Eight $(50 \%)$ of the interviewed teachers stated that the given sentences were inadequate and did not fit the students' levels. They stated that the given sentences should be short and at a level that the children can understand. In addition, they pointed out that the students had difficulty in sentences as they start sentence stage without sufficient activity and practice in the previous steps. A teacher says: 'Students have difficulty in reading and writing the sentences as they pass without comprehending the letters and syllables. He can grasp it in his notebook and on the board after abundant repetition. At that time, it is necessary to prepare separate pictures and images for the notebook. This leads to loss of time for us and the student '(Teacher, 16).

The eight teachers who participated in the interviews stated that the sentences given to students with intellectual disabilities about reading in literacy teaching were appropriate and sufficient.

\section{Opinions Regarding Priority in Books Used in Literacy Teaching- Writing or Reading}

Four $(25 \%)$ of the teachers interviewed stated that they were primarily interested in reading in books used in literacy teaching, and that writing activities were in the second place. However, they emphasized that the given activities were not sufficient in terms of the development of both reading and writing skills. For example, a teacher said, 'I think that the given activities are not enough for the development of both skills.' They only suggest sorting and guiding to what is taught (Teacher, 10). Complete acquisition of literacy skills consists of reading, reading comprehension, and dictated writing skills, so these three areas should be adequately active.

Twelve (75\%) of the interviewed teachers reported that the given activities were equally well-suited for the development of reading and writing skills. 


\section{Opinions Related to Reading Texts, Word-Sentence and the Use of Hints (Picture Vb.)}

All of the interviewed teachers were agreed on that pictures and images are very important in teaching reading and writing skills, especially the clues and images used for children with intellectual disabilities. However, 87.5\% of the teachers (14) stated that text-image visual relations in the books used were not sufficient for children with intellectual disabilities. For example, a teacher: 'It is tried to put pictures for words and phrases, but the pictures are small and not very interesting '(teacher, 4), another teacher; 'Visuals are not enough' (teacher, 1). 12.5\% of the teachers who participated in the interviews stated that the images provided by the picture-text relation in the books used were adequate.

\section{Opinions on the appropriateness of Books Used in Literacy Teaching Regarding IEP Goals}

Teachers have expressed various views on the appropriateness of the books used in literacy teaching regarding IEP goals. A teacher stated that the activities in the books are appropriate for the order of reading-writing instruction, but they do not include the activity pages for evaluating the achievement and reinforcing them. 'It is suitable for guidance in ordering but inadequate for measurement and evaluation. (Teacher, 4)'. 9 of the teachers interviewed indicated that the sequence of events in the books was appropriate for IEP goals, but because the levels of the students in the class were very different from each other and that they cannot provide sufficient efficiency to achieve their goals. A teacher reported this opinion: 'Students who are literate at different levels in the same class cannot work with attaching to a book. The level of each student is different. Needs individual study '(Teacher, 8). Four of the teachers said that the books did not fit the objectives of the IEP. The opinion of a teacher is; 'It is not suitable for IEP, most of them are above the level. We cannot do classical literacy work that you know with most students' (Teacher, 6). Two of the interviewed teachers indicated that the books fit the IEP. 


\section{Opinions on Additional Materials in Literacy Teaching}

All of the interviewed teachers stated that they needed supplementary material in teaching reading and writing for children with intellectual disabilities and that the students' levels and learning characteristics were very different from each other, increasing the need for materials that address different senses. The opinion of a teacher is: 'Yes, I need it. I download videos and pictures from the internet. In my class, there is an interactive board; I open songs, games and visuals. In addition, I am writing small squares on top of board and I draw a picture on the sentence, syllable, sound. I have picture cards ready for the letters, I use them '(Teacher, 5). Another teacher said: 'I need additional material. I make visual and auditory contributions to smart boards' (Teacher, 13). Teachers who participated in the interviews stated that the presence of students at different levels in the same class increased the need for different materials and that working in a single book adversely affects the motivation of the students. A teacher has expressed this opinion: 'I have two students in my class who have gained literacy skills. I'm doing studies to improve reading comprehension with these kids. I provide simple story books, I use primary school 1,2,3 Turkish books' (Teacher, 6).

\section{Opinions on Homework Efficiency of Books Used in Literacy Teaching}

All of the interviewed teachers stated that repetition at home was very important in their literacy work, but that books used in literacy teaching were not enough for homework. A teacher reported that 'a few sentences were left blank, and there is no activity page in the form of working paper outside the writing area. It is not enough. '(Teacher, 13). Teachers are aware of the fact that families need to actively participate in the process and repeat the work done in class at home and support their literacy work with different materials and activities but that a large part of the students come from low social and cultural backgrounds and that family and society do not give importance to the education of the child. One of the teachers expressed their views: 'There is very little activity page for homework in the book we use in the literacy teaching. These kids need to do plenty of repetition. It can be used from different sources. But most of the families are very low in the level of education, they do not know 
how to study. Although we try to guide, it is not very effective '(Teacher, 3).'The level of each student is different. It is very difficult for us to have enough time for each one. They need to do it again at home. But there are not enough activity pages in the book. I myself prepare homework paper from different sources and give it to the students' (Teacher, 7).

\section{Discussion and Conclusion}

As regarding the textbook used in the literacy teaching, the teachers stated that the books used in literacy teaching are written in plain text and that the plain writing is appropriate. They pointed out the importance of its being suitable for daily life, the ability of children with intellectual disabilities to grasp the straight line more easily, and it is also easy writing in terms of motor development. When literature is examined, it is seen that different methods are used in literacy teaching in the historical process (Bay, 2006). However, there is no specific literacy teaching method specific to children with intellectual disabilities. The mental level of the child requires the choice of either functional reading instruction or one of the literacy teaching methods (Browder and Snell, 2000). Method diversity should include applications that address primarily the learning styles and needs of students (Baş, 2006). Teachers considering that they adopt the idea that hand writing are more difficult to perceive and that vertical writing is appropriate for the learning situations of children with intellectual disabilities, agree with Browder and Snell (2000) and Baş (2006).

Most of the teachers participated in the study about the adequacy of the types and number of activities given in the literacy teaching books stated that the activities in the textbooks used for reading and writing teaching for the students with intellectual disabilities were not suitable for these children and level and the number of activities were also insufficient. Teachers stated that the activities in the books are mostly visual and auditory; especially special students should be involved in activities and games that appeal to different senses while teaching reading and writing. It is emphasized that the activities for the students with intellectual disabilities in the literacy teaching should be as appealing as possible to the senses. (Çelenk, 1999, Güleryüz, 2000, Koksal, 2000, Nas, 1999). In this study, the teachers emphasized that the activities should be increased and there should be activities that appeal to different 
senses, and increase the attention and motivation of the students. Therefore, the findings of Çelenk (1999), Güleryüz (2000), Koksal (2000) and Nas (1999) support the findings obtained from this research. Teachers stated that the stages of literacy teaching students with intellectual disabilities are not different from normal children, only the teaching process is longer and the type and number of activities should be increased according to learning situations and characteristics of students. As a result of research made by Çolak (2001) it is expressed that children with intellectual disabilities follow the same process as children with normal development in learning literacy but complete these stages for a longer time than children who showed normal development. In this study, teachers seem to have similar opinions. Therefore, the findings obtained from this study are parallel with those obtained from Çolak's (2001) study.

In the books used in literacy teaching, teachers pointed out different views on which of the reading and writing skills are priorities. Some of the teachers indicated that reading skills were given priority, and writing activities came in second place. Most of the teachers who participated in the interviews expressed that they were cooperating together in two activities. Therefore, this shows that the teachers carry out the literacy activities together. As a matter of fact, Special Education Services Support Education Services Training-Application School Training Program, in the section of explanations about ReadingWriting Course; 'Literacy must always be carried out together, sentences and words that children learn to read should be written at the same time. Children should learn how to read the sentences and words before they read and then they should write : However, all of the teachers have reached a common point of view and emphasized that the given activities are not sufficient in terms of the development of both reading and writing skills.

Teachers reported different opinions about the suitability of the books used in literacy teaching to the purposes of the IEP. Some of the teachers pointed out that the activities in the books were appropriate in terms of guiding the sequence to be followed in the reading and writing teaching, but that the activities were very inadequate, there were no activities to reinforce and evaluate. It can be said that moving on to the next stage before an effective assessment makes the reading and writing teaching process difficult. Some of the teachers stated that the activities in the books fit into the objectives of the IEPs but that the students 
in the class cannot include individual intensive literacy activities because the levels are very different from each other. In a project conducted by Southern Methodist University (2005), a total of 150 students in ten different schools were examined. Half of the pupils continued intensive reading lessons for about an hour a day while the other half continued to be trained according to the normal program of mental retardation school. The results showed that the students achieved significantly better results than the students according to the usual methods. Teachers' expressions of individualized intensive support education for the teaching of literacy in students with intellectual disabilities are similar to this research. Some of the interviewed teachers stated that the levels of students were very different and that their needs for learning to read and write varied. However, they stated that the books used in literacy teaching were not in line with the aims of the IEP, and that they were well above the level of the students. One of the preconditions for independent living in society is to gain the functional reading skills. The most important goal of teaching literacy to students with intellectual disabilities is to help these students improve their confidence in themselves, socialize and support their mental and motor development. For this reason, the literacy skills should be taught according to the performance and needs of the students with intellectual disabilities (Başal and Batu, 2002). Therefore, the achievement of functional literacy skills for each child is not a process that is continued by following the reading and writing teaching sequence as in the textbooks. However, the majority of the teachers participating in the study gave the impression that the teachers teach in terms of the sequence in the books, rather than using practices that will enable students to acquire functional literacy skills in the literacy teaching process.

All of the interviewed teachers indicated that they needed supplementary material in teaching reading and writing to intellectually disabled children. The fact that the students' levels and learning characteristics are very different from each other increases the need for materials that appeal to different senses. Teachers have stated that the presence of students at different levels in the same class increases the need for different materials and to study in a single book affects the motivation of students negatively. They point out that they try to enrich literacy activities as much as possible by using interacting boards, playing cards, picture cards, songs, games and simple story books 
depending on the needs of the students. The use of different materials in instructional activities reveals the efforts of teachers in teaching reading and writing to students with intellectual disabilities.

As a result, teaching literacy for students with intellectual disabilities is important not only in providing a basis for teaching functional academic skills, but also for enhancing the confidence of students, helping them to socialize, and supporting their mental and motor development. The achievement of literacy skills increases the level of participation in activities with other students according to the educational environment they are in. The textbooks that are among the teaching materials have an important place in the teaching of literacy skills. In acquiring functional literacy skills, which is one of the prerequisites for independent living in the community, teachers need to adapt textbooks prepared for children with normal development to be used with children with intellectual disabilities and to teach reading and writing skills according to the performance and needs of students. Children with intellectual disabilities learn to read and write at the same stages as normal children. However, this process is long-lasting. In the reading and writing process, the curriculum should be determined according to the needs of the learners and the activities should be increased, designed to appeal to the greatest possible senses, the motivation of the students should be kept at the highest level.

Suggestions for further research:

1. The research can be designed in different educational settings by different participants and different researchers.

2. The opinions of teachers from different branches and the opinions of special education teachers can be evaluated comparatively.

3. The methods that teachers mostly prefer to teach reading and writing to students with intellectual disabilities can be evaluated in terms of the opinions of teachers who are special education graduates and not.

Suggestions for implementation:

1. Seminars should be organized for teachers who are not special education graduates, on to improve proficiency in literacy teaching methods and material enrichment for students with intellectual disabilities. 
2. A functional literacy curriculum should be prepared by determining the performance and needs of students with intellectual disabilities.

3. Materials that can be used in literacy teaching to students with intellectual disabilities should be increased.

4. Informative activities for families should be organized and the family must be included in the process.

\section{References:}

Anstötz, C. (1987): Grundriß der Geistigbehindertenpädagogik. Berlin: Marhold Bach, H. (1977): Geistigbehindertenpädagogik (8. unveränderteAufl.). Berlin: Marhold.

Baş, Ö. (2006). Ses Temelli Cümle Yöntemi ve Bitişik Eğik Yazıyla İlkokumaYazma Öğretiminde Alternatif Harf Sıralaması.Ulusal Sınıf Öğretmenliği Kongresi. (14-16 Nisan 2006). Ankara:Gazi Üniversitesi.

Bapal, M. \& Batu, S. E. (2002). Zihin özürlü öğrencilere okuma yazma öğretme konusunda alt özel sını öğretmenlerinin görüş ve önerileri. Özel Eğitim Dergisi, 3 (2), 85-97.

Bay, Y. (2006). Cumhuriyetten Günümüze İlk Okuma-Yazma Öğretim Sürecinin Tarihsel Gelişimi. Ulusal Sınıf Öğretmenliği Kongresi. (14-16 Nisan 2006). Ankara: Gazi Üniversitesi.

Browder, D.M. ve Snell, M.E. (2000). Teachingfunctionalacademics. In M.E. Snell ve F. Brown (Ed). Instruction of studentswith setere disabilities, (ss. 493-543). New Jersey; Merrill Publishing Company.

Cavkaytar, A. (2001) Zihin engellilerin eğitim amaçları. Anadolu Üniversitesi Eğitim Fakültesi Dergisi, 10,(1).

Çelenk, S. (1999) İlkokuma Yazma Öğretimi. Artım Yayınları. Ankara.

Çelenk, S. (2005). İlkokuma Yazma Programı ve Öğretimi. Ankara: Anı Yayıncılık

Çolak, A. (2001). Zihin özürlü çocuklar ilköğretim okulu ve mesleki eğitim merkezindeki özel eğitim Öğretmenlerinin zihin Özürlü çocukların okuma-yazma Öğrenmeleri hakkındaki görüşve önerileri. Yayınlanmamış yüksek lisans tezi, Anadolu Üniversitesi, Eskişehir.

Gunning, T.G. (1996). Creatingreadinginsructionforallchildren (2nd Ed.). Boston: Allynand Bacon.

Güleryüz, H. (2004). Türkçe İlkokuma Yazma Öğretimi. Ankara: Pegem A Yayıncılık.

Hoogeveen, F.R.,Smeets, P.M. ve Lancioni, G.E. (1989). Teachingmoderatlymentallyretardedchildrenbasicreadingskills. Research in DevelopmentalDisabilities, 10(2), 1-18. 
Karasar, N. (2010). Bilimsel Araştırma Yöntemleri. Nobel Yayınları, 21. Baskı, Ankara

Katims, D. S. (2001): LiteracyAssessment of StudentswithMentalRetardation: An ExploratoryInvestigation.Educationand Training in MentalRetardationandDevelopmentalDisabilities. 36(4), S. 363-372

Kavcar, C.,Oğuzkan, F. ve Sever, S. (1998). Türkçe Öğretimi. Ankara: Engin Yayınevi.

Koch,A. (2008). DieKulturtechnikLesen im UnterrichtfürSchüler mit geistigerBehinderung. LesenlernenohnePhonologischeBewusstheit?DissertationzurErlangungdesDoktorgrades (Dr. phil.) desFachbereichesGesellschaftswissenschaftender JustusLiebig-UniversitätGießen.

Koksal, K. (2000). Okuma yazmanın öğretimi. Ankara: Pegem Yayıncılık.

Koller, J. (1969): IntelligenzundLeseleistungenbeiGeistesschwachenleichterenundmittlerenGrades.HeilpädagogischeWerkblätter, S. 129-133

Love, H.D. ve Litton. F.W. (1994). Teachingreadingtodisabledandhandicappedlearners. Illinois: Charles C. Thomas Publisher.

M.E.B. (2001). İlköğretim Okulu Otla Düzeyde Öğrenme Yetersizliği Olan (Eğitilebilir) Çocuklar Eğitim Programı. Ankara: Milli Eğitim Basımevi.

Nas, R. (1999). Metinlerle ilkokuma yazına öğretimi. Bursa: Ezgi Kilabevi.

Oberacker, P. (1980): Sprechen, Lesen, Schreiben mit geistigBehinderten. VillingenSchwenningen: Necker-Verlag.

Öz, M. F. (2005). Uygulamalı İlk Okuma Yazma Öğretimi. Ankara: Anı Yayıncılık

Özdemir, E. (1995). Okuma Sanatı. İstanbul: İnkılap Kitapevi

SMU(2005):Project Maximize. Verfügbarunter: http://www.smu.edu/teacher_education/IRR/maximize.asp [10.10. 2017].

Speck, O. (1975): Der geistigbehinderteMenschundseineErziehung. München: Reinhardt.

Türnüklü, A. (2000). Eğitimbilim Araştırmalarında Etkin Olarak Kullanılabilecek Nitel Bir Araştırma Tekniği: Görüşme. Kuram ve Uygulamada Eğitim Yönetimi, (24), 543-559.

Yıkmış, A. (1999) Zihin engelli çocuklara temel toplama ve çıkarma işlemlerinin kazandırılmasında etkileşim ünitesi ile sunulan bireyselleştirilmişöğretim materyalinin etkililiği. Yayınlanmamış Yüksek Lisans Tezi, Eskişehir. Anadolu Üniversitesi Eğitim Bilimleri Enstitüsü.

Yıldırım, A. ve Şimşek, H. (2004). Sosyal Bilimlerde Nitel Araştırma Yöntemleri. Ankara: Seçkin Yayıncılık.

Yıldırım, A. Ve Şimşek, H. (2006). Nitel Araştırma Yöntemler. Ankara: Seçkin Yayıncilik 